\title{
Ambient Stresses Regulate the Development of the Maize Late Wilt Causing Agent, Harpophora maydis
}

\author{
Ofir Degani ${ }^{1,2 *}$, Yuval Goldblat ${ }^{1}$ \\ ${ }^{1}$ Tel-Hai College, Tel-Hai, Israel \\ ${ }^{2}$ Migal-Galilee Research Institute, Kiryat Shmona, Israel \\ Email: ${ }^{*}$-ofir@bezeqint.net, ${ }^{*}$ ofird@telhai.ac.il
}

Received 17 April 2014; revised 17 May 2014; accepted 28 May 2014

Copyright (C) 2014 by authors and Scientific Research Publishing Inc. This work is licensed under the Creative Commons Attribution International License (CC BY). http://creativecommons.org/licenses/by/4.0/

(c) (i) Open Access

\section{Abstract}

Late wilt, a severe vascular disease of maize caused by the fungus Harpophora maydis, is characterized by relatively rapid wilting of maize plants before tasseling and until shortly before maturity. In Egypt and Israel, the disease is considered to be a major problem. The pathogen is currently controlled using cultivars of maize having reduced sensitivity, but the fungi can undergo pathogenic variations and become a threat to resistance cultivars as well. The abiotic and biotic factors influencing the infection and disease development are not fully determined. To impose stress in a uniform and chronic manner, we expose the Israeli $\boldsymbol{H}$. maydis isolates colonies or spores to light, different $\mathrm{pH}$, ionic and hyperosmotic pressures (induced with $\mathrm{KCl}$ or sorbitol) or oxygen-related stresses (induced with oxygen enrichment, menadione or peroxide). The optimum pH for both hyphal development and spore germination was $\mathrm{pH}=5-6$, similar to reports for the Egyptian, Indian and Hungarian isolates of $\boldsymbol{H}$. maydis. In the hyperosmotic regime, hyphal growth was affected in a dosage-dependent curve. Although inoculation under high salt stress also inhibited spore germination, the spores were relatively resistant to this stress in comparison to the hypha. An opposite picture was revealed under menadione/peroxide stress: under high dosage of these compounds, the spore germination was virtually abolished while the colony growth was moderately affected. A daily oxygen enrichment of liquid medium cultures caused an increased growth in the pathogen wet and dry biomass, but daily double treatments led to growth suppression. These findings are a preliminary step towards the inspection of the fungal-host interaction under these different stressful environments. This is important for the future development of new strategies to restrict the disease burst and to protect field corps.

\section{Keywords}

Acremonium maydis, Black Bundle Disease, Cephalosporium maydis, Environment Stress, Fungus,

\footnotetext{
${ }^{*}$ Corresponding author.
} 


\section{Introduction}

Late wilt or black bundle disease is a vascular wilt disease of Zea mays (corn, maize) caused by the soil-borne and seed-borne fungus, Harpophora maydis [1] [2] with synonyms Cephalosporium maydis and Acremonium maydis [2] [3]. The fungus reproduces asexually, and no perfect stage has been identified [4]. Late wilt was reported in Egypt [5], India [6], Hungary [7], Israel [8], Spain and Portugal [9]. Serious economic losses from late wilt have been reported in Egypt, where 100\% infection occurs in some fields, and in India, with an incidence as high as $70 \%$ and economic losses up to 51\% [10]. The Egyptian, Indian and Hungarian isolates of H. maydis differ in morphology, pathogenicity and route of infection [11]. The four clonal lineages of Egyptian isolates of H. maydis show diversity in amplification fragment length polymorphism (AFLP), and differ in colonization ability and virulence on maize [4] [12]-[14].

Late wilt disease is characterized by relatively rapid wilting of maize plants, typically at the age of 70 to 80 days, before tasseling and until shortly before maturity. First symptoms appear approximately 60 days after sowing [15]. With disease progression, the lower stem dries out (particularly at the internodes) and has a shrunken and hollow appearance, with dark yellow to brownish macerated pith and brownish-black vascular bundles [16]. Late wilt is often associated with infection by secondary invaders causing the stem symptoms to become more severe [17] [18]. Fewer ears are produced, and kernels that are formed are poorly developed [8] and may be infested with the pathogen. Seed quantity is correlated negatively to disease severity [19].

Spread is primarily through movement of infested soil, crop residue, or seed-borne inoculum. $H$. maydis can survive in seeds for 10 months at high temperatures and low humidity in India, but longer survival is predicted at low temperatures [20]. Infested seeds can produce plants with late wilt symptoms, infest soil and result in the subsequent development of late wilt in healthy seeds grown in that soil. The most effective control of late wilt is using resistant germplasm [4] [21], although some agricultural, biological and chemical controls can reduce its impact on commercial production. Various agricultural measures such as soil solarization, balanced soil fertility and flood fallowing can reduce disease severity and losses. Inoculum survival is restricted to the top $20 \mathrm{~cm}$ of soil, and survival depends primarily on the persistence in infested crop residues [22].

Previous studies indicate that moisture stress is a major predisposing factor to stalk rots [23] and that more frequent watering of maize plants is associated with a decrease in percentage of late wilt disease infection and an increase in yield per plant [2] [24]. The association of symptom development with disturbance in water relationships of infected plants has been demonstrated for several vascular diseases [25].

To date, the valuation of the ability of $H$. maydis to cope with stressful environments focused on defining optimal temperature and $\mathrm{pH}$ conditions for the Egyptian, Indian and Hungarian isolates. Optimum temperature and moisture conditions for corn growth also are optimal for disease development [11]. Thus, late wilt develops rapidly at $20^{\circ} \mathrm{C}-32^{\circ} \mathrm{C}$, with optimum disease development at $28^{\circ} \mathrm{C}-30^{\circ} \mathrm{C}$ [20]. Growth of $\mathrm{H}$. maydis in soil is sharply inhibited above $35^{\circ} \mathrm{C}-36^{\circ} \mathrm{C}$ and minimal growth was recorded at $8{ }^{\circ} \mathrm{C}-12^{\circ} \mathrm{C}$ [7] [26]. This fungal pathogen can grow over a wide range of soil pH from $4.5-10$, with an optimum at $\mathrm{pH}=6.5$ [27]. The optimal temperature for the development of the pathogen is especially important since global warming and the dry weather experienced in the early summer in the last few decades may play a decisive role in the pathogen's appearance and activity [7].

Nevertheless, other environmental factors such as salt and oxidative stress are likely to be important and affect the predisposition of maize plants to late wilt, as demonstrated in other cases (for example, [28]). The use of poor water quality can result in various soil and cropping problems, including salinity (osmotic) stress. Reactive oxygen species (ROS), either hydrogen peroxide $\left(\mathrm{H}_{2} \mathrm{O}_{2}\right)$, the hydroxyl radical $(\mathrm{OH})$, or superoxide anions ( $\left.\mathrm{O}_{2}^{-}\right)$, are generated endogenously in many plant cells as a consequence of metabolic processes such as respiration, and also by the immune system in response to pathogens [29]. All these factors could affect the pathogen and its host interrelationship.

Here, we assess the influence of light, $\mathrm{pH}$, ionic and/or hypertonic and oxidative chronic stress conditions on the spore germination and hyphal growth rate of Israeli $H$. maydis isolates under controlled conditions. A better understanding of optimal environmental conditions for pathogen development as well as its response to various 
kinds of stress may assist in predicting its potential spread and in applying agro-technical means to protect crops.

\section{Materials and Methods}

\subsection{Fungal Isolates}

Four isolates of $\mathrm{H}$. maydis,called $\mathrm{Hm}-1, \mathrm{Hm}-2, \mathrm{Hm}-3$ and $\mathrm{Hm}-4$ (three of them currently deposited at the CBSKNAW Fungal Biodiversity Center, Utrecht, The Netherlands, under the numbers: CBS 133164, CBS 133165 and CBS 133166) were used in this study. These $H$. maydis strains were recovered from wilting maize plants (Zea mays L., Jubilee cv., Syngenta, Fulbourn, Cambridge, UK) sampled from a maize field in Sde Nehemia in the Hula Valley of the Upper Galilee (northern Israel) in 2001. The pathogenicity of the Israeli H. maydis isolates was confirmed by complying with Koch's postulates, and the pathogen was characterized by its colony morphology and microscopic traits [8]. The morphological and microscopic characteristics of the pathogen were identical to those of previously described strains found in Egypt and India [6] [26]. Final confirmation was achieved by PCR-based DNA analysis [8].

\subsection{Normal and Stress Conditions in Solid Media Culture}

All isolates were grown on potato dextrose agar (PDA) (Difco, Detroit, MI, USA). Media for the stress-response experiments were prepared by adding $\mathrm{KCl}$ (Sigma-Aldrich; final concentration of $0.25-1 \mathrm{M}$ ) or sorbitol (Sigma-Aldrich; final concentration of 0.5 - $2 \mathrm{M}$ ) to PDA prior to autoclaving. Menadione sodium bisulfite (2-Methyl-1, 4-naphthoquinone sodiumbisulfite, Sigma-Aldrich; 50 - $300 \mu \mathrm{M}$ final concentration, from a $50 \mathrm{mM}$ ethanol stock), which generates superoxide anion radicals [30], or 2 - $10 \mathrm{mM}$ hydrogen peroxide (Sigma-Aldrich; final concentration) was prepared by sterilizing the solutions by filtering through a $0.2 \mu \mathrm{m}$ syringe filter and adding them to autoclaved PDA after it had cooled down to $55^{\circ} \mathrm{C}$. To study the effect of $\mathrm{pH}$ conditions on the colonies' growth rate, the PDA media $\mathrm{pH}$ was adjusted to final values of 2, 4, 6, 8, 10 and 12 with $1 \mathrm{M}$ or 100 $\mathrm{mM} \mathrm{HCl}$ or $\mathrm{NaOH}$ stock solutions. All chemicals were analytical reagent grade. Twenty five milliliters of these PDA modified media were poured into a $9 \mathrm{~cm}$ diameter petri dish. Each stress media plate, including the control (with PDA only), was inoculated on solidification in the middle with a $6 \mathrm{~mm}$ (in diameter) culture agar disk cut from the margins of 4 - 6-day-old $H$. maydis colonies. Labeled petri dishes were placed in an incubator at $28^{\circ} \mathrm{C}$ $\pm 1^{\circ} \mathrm{C}$ in the dark. In the light sensitivity experiment, the isolates were grown at $28^{\circ} \mathrm{C} \pm 1^{\circ} \mathrm{C}$ in continuous light from cool white fluorescent tubes (Philips, Eindhoven, The Netherlands), and the dark growing culture plates were covered with aluminum foil and maintained under the same conditions. Radial mycelial growth was taken after inoculation at two-day intervals (unless otherwise indicated) by measuring the diameter along two perpendicular lines from the underside of the petri dishes with a digital caliper. All treatments (stressing agents at different rates and the control) were performed in five to six independent replications and in at least two independent experiments.

Data analysis of the plate sensitivity assay. Each of the set conditions (i.e., stressing agent concentrations) generated an approximately linear growth curve of the mean colony diameter against the growth days. The slope for each curve determined and a new graph generated from all of the slopes plotted the growth rate (expressed in $\mathrm{mm} \cdot \mathrm{day}^{-1}, \mathrm{Y}$ axis) against the concentration of the stressful compound (X axis). In the resulted regression curves, the $R^{2}$ (coefficient of determination) is a statistical measure of how well the regression line approximates the real data points. The coefficient of determination ranges from 0 to 1 (an $R^{2}$ of 1 indicates that the regression line perfectly fits the data). Statistical analysis, conducted using Student's $t$ test, verified whether differences were statistically significant $(P \leq 0.05)$.

\subsection{Effect of Oxygen Enrichment on the Liquid Media Cultures}

To enrich the colonies with oxygen, we used a method described earlier [31]. Four colony agar disks (6-mmdiameter each, taken from the margins of a 5-day-old colonies) were added to a 250-ml Erlenmeyer flask containing $150 \mathrm{ml}$ of autoclaved sterile potato dextrose broth (PDB, Difco, Detroit, MI, USA). The submerged liquid cultures were grown at $28^{\circ} \mathrm{C} \pm 1^{\circ} \mathrm{C}$ in the dark on a rotary shaker at $150 \mathrm{rpm}$. The flasks were sealed with rubber stoppers, and the headspace was flushed once or twice a day with $\mathrm{O}^{2}$ for $1 \mathrm{~min}$ at a flow rate of 2 li- 
ter/min (oxygenated cultures). Oxygen gas was of medical-grade purity. Cultures grown with free exchange of atmospheric air (flasks sealed with dense paper plugs) served as controls. Cultures were incubated for 6 - 9 days, as indicated separately for each experiment. At the end of the experiment, the mycelium was harvested by filtrating it from the media using a Buchner funnel and two pre-weighed No. 3 Whatman filters for each treatment. The filter papers with fungus wet weight were measured immediately. Afterwards the filter papers with fungus were dried at $70^{\circ} \mathrm{C}$ for $48 \mathrm{~h}$ in a hot air oven and the dry mycelial weight was measured. Each assay was performed in 3 - 6 independent replications and the entire experiment was repeated twice.

\subsection{Effect of Environmental Stresses on H. maydis Spore Germination}

To induce sporulation, cultures were grown at $28^{\circ} \mathrm{C} \pm 1{ }^{\circ} \mathrm{C}$ in a humid atmosphere on the PDA surface. After four days, as previously described [26], spores were harvested by washing them and scraping them off the agar surface with $1 \mathrm{ml}$ sterile deionized water. The spore suspension was kept at $4^{\circ} \mathrm{C}$ for up to one day. The spores (final concentration of 50 spore's $\mu \mathrm{l}$ ) were suspended in watery solutions containing different $\mathrm{pH}$ values, $0.75 \mathrm{M}$ $\mathrm{KCl}, 1.5 \mathrm{M}$ sorbitol, $200 \mu \mathrm{M}$ menadione or $10 \mathrm{mM}$ peroxide, aimed at challenging the spores under stress conditions. The spores' suspensions in Eppendorf tubes were then incubated in a rotary shaker at $150 \mathrm{rpm}$ at $28^{\circ} \mathrm{C} \pm$ $1{ }^{\circ} \mathrm{C}$ in the dark. The percentage of germinating conidia was determined after incubation (for the times specified for each experiment) by direct counting in $2 \mu \mathrm{l}$ drops on a glass slide using a light microscope equipped with a Moticam 5 (Motic Instruments, Richmond, Canada) microscope camera. The criterion for germination was the observation of any germ tube emerging from the spores examined. Each assay was performed in 3 - 6 independent replications and the entire experiment (for each stress condition) was repeated twice.

\section{Results}

During growth on maize, $H$. maydis is likely to be subject to various kinds of stress. We therefore conducted a well-controlled inspection of the pathogen in modified media in order to identify its behavior under light, various $\mathrm{pH}$, osmotic and ionic, and oxidative stressful environments. Dark-grown colonies grew significantly faster than light-grown ones $(P<0.05)$, covering a $90-\mathrm{mm}$ plate within six days (Figure 1 ). This result is expected since the pathogen's natural environment is beneath the ground surface and within the vascular system of the host.

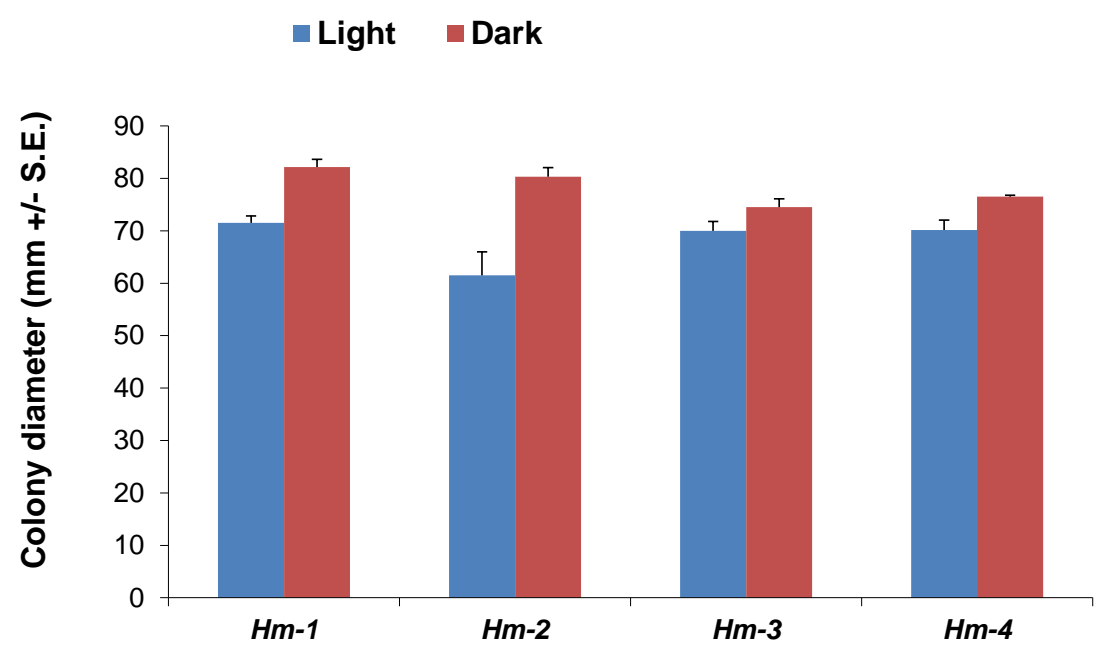

Figure 1. Harpophora maydis strains growth rate under light or dark conditions. Assay plates were inoculated in the middle with a $6 \mathrm{~mm}$ (in diameter) culture agar disk cut from the margins of 4 - 6-day-old $H$. maydis colonies. Four isolates of $H$. maydis (called $\mathrm{Hm}-1, \mathrm{Hm}-2, \mathrm{Hm}-3$ and $\mathrm{Hm}$-4) were grown on potato dextrose agar (PDA) at $28^{\circ} \mathrm{C} \pm 1{ }^{\circ} \mathrm{C}$ in complete darkness (achieved by covering each growth plate with aluminum foil) or in continuous light from cool white fluorescent tubes. Radial mycelial growth was taken six days after inoculation. Values represent an average of six replications. Error bars indicate standard error. 


\subsection{Effect of the pH Growth Condition on Mycelial Growth and Spore Germination}

The host environment can differentially govern the outcome of infection when fungal pH adaptation is inappropriate. To assay the various ambient $\mathrm{pH}$ values on $H$. maydis development, we used plate's sensitivity and spore germination assays. Extreme acidic and alkaline adjusted growth media prevented both the hyphal growth and spore germination of the pathogen (Figure 2). Nevertheless, a relatively wide range of moderate $\mathrm{pH}$ values of 4 - 8 (with optimal peak around pH 5 - 6) enabled a high spore germination and culture proliferation of the fungi (Figure 2). From the data, the $\mathrm{pH}$ values similarly affect the hypha and the spores.

\subsection{Plate's Sensitivity and Spore Germination Assays to Osmotic and Ionic stress}

Water potential caused by drought or hypertonic environments is a major factor affecting plants, but it can also affect their parasitic fungi. To induce low water potential (activity), the mycelium was grown on PDA enhanced with increased levels of $\mathrm{KCl}$ (hyperosmotic and ionic stress) or sorbitol (hyperosmotic stress). Under optimum conditions on PDA media and at $28^{\circ} \mathrm{C} \pm 1{ }^{\circ} \mathrm{C}$, the pathogen grows at its highest rate-15 mm a day (Figure 3 and Figure 4). This colony’s growth rate declined steeply with increasing osmotic pressure. At the highest levels of $\mathrm{KCl}$ and sorbitol tested, the fungus showed only slight growth; colony diameter growth rate reached 2 mm a day (Figure 3). There was no evident difference between the $\mathrm{KCl}$ and sorbitol stresses, although the salt causes a combined influence that included hypertonic and ionic pressures. Interestingly, unlike in the pH sensitivity assay (Figure 2) in which spore germination ceased under harsh conditions, here the spores' germination was only delayed under the influence of $0.75 \mathrm{M} \mathrm{KCl}$ or $1.5 \mathrm{M}$ sorbitol, reaching approximately $80 \%$ after $16 \mathrm{~h}$ (the non-treated control spores reached near 100\% germination after $10 \mathrm{~h}$ ) (Figure 5). This difference from the control was significant $(P<0.05)$ from 10 h incubation onwards, in both treatments $(\mathrm{KCl}$ and sorbitol). Germinating conidia tended to adhere to each other and form aggregates in a way similar to some of the other phytopathogens [32] [33] (Figure 5(b)).

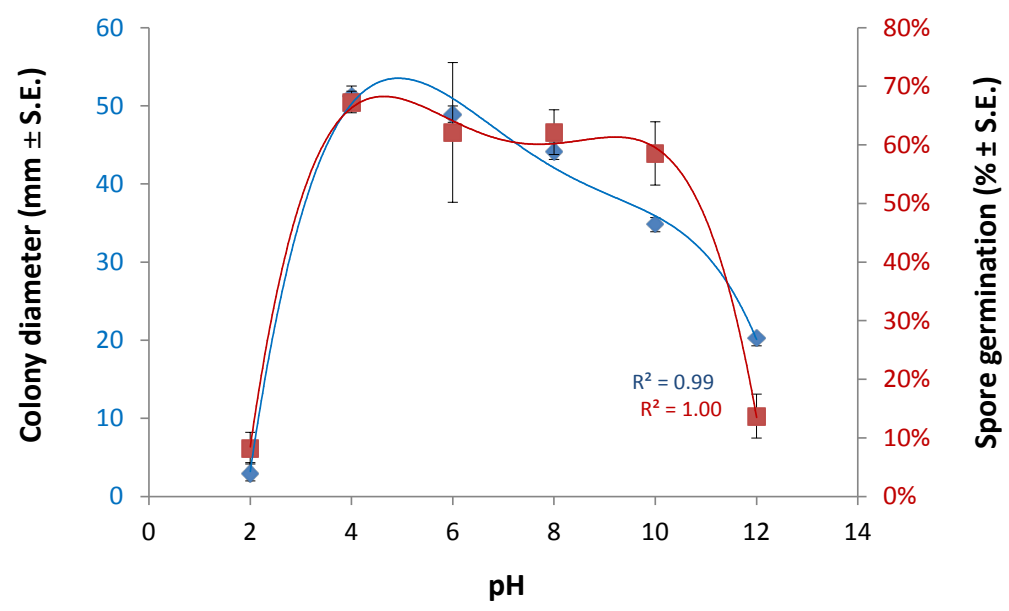

Figure 2. Effect of $\mathrm{pH}$ on $H$. maydis growth and spore germination. To study the effect of $\mathrm{pH}$ conditions on the colonies' growth rate, the PDA media $\mathrm{pH}$ was adjusted to final values of 2, 4, 6, 8, 10 and 12 with $1 \mathrm{M}$ or $100 \mathrm{mM} \mathrm{HCl}$ or $\mathrm{NaOH}$ stock solutions. Plates were inoculated as described in Figure 1 and incubated at $28^{\circ} \mathrm{C} \pm 1{ }^{\circ} \mathrm{C}$ in complete darkness. For the spore germination assay, spores were washed from the agar surface of 4-day-old colonies grown under the above conditions and suspended in watery solutions, containing the $\mathrm{pH}$ values described above. The spores' suspensions in Eppendorf tubes were then incubated in a rotary shaker at $150 \mathrm{rpm}$ at $28^{\circ} \mathrm{C} \pm 1^{\circ} \mathrm{C}$ in the dark. Evaluation of the colony mycelial growth rate was done four days after inoculation, and spore germination assessment was made six hours after inoculation. Values represent the average of two experiments, each containing six (for the colony growth experiment) or three (for the spore germination assay) independent replicates. Error bars indicate average standard errors. The $R^{2}$ (coefficient of determination) is a statistical measure of how close the data are to the fitted regression line (an $R^{2}$ of 1 indicates that the regression line perfectly fits the data). 


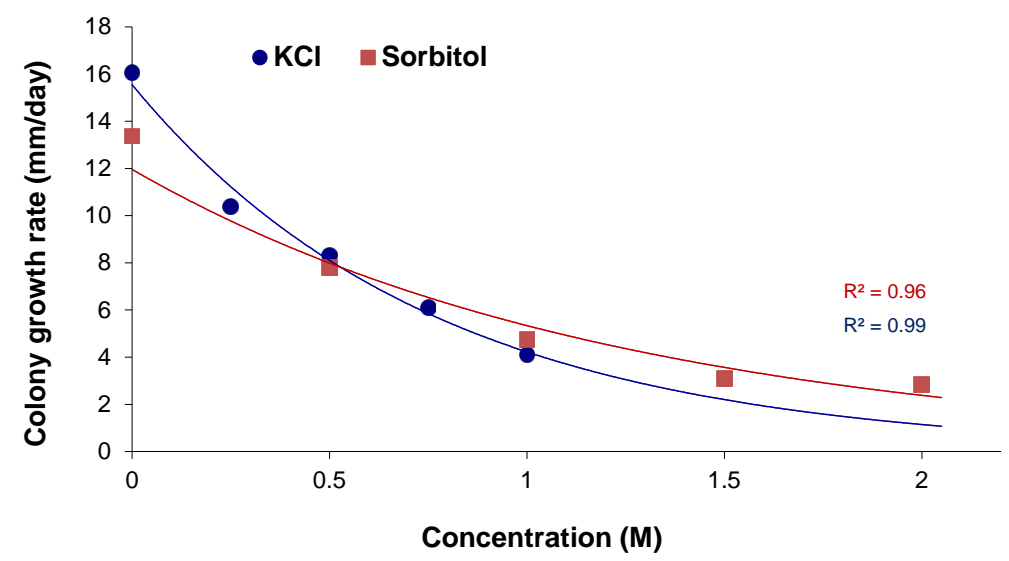

Figure 3. Osmotic and ionic stress-response phenotypes. Quantitative growth rate data for $H$. maydis on the PDA media plates containing $\mathrm{KCl}$ or sorbitol (final concentration of $0.25-1$ and $0.5-2 \mathrm{M}$, respectively) to evaluate ionic and osmotic stress. Plates were inoculated as described in Figure 1 and incubated at $28^{\circ} \mathrm{C} \pm 1{ }^{\circ} \mathrm{C}$ in complete darkness. Growth rates are averages of six replicate cultures determined by the slope of the growth curve generated from measurements taken 2, 4, 6, 8 days after inoculation. Error bars indicate standard error. The $R^{2}$ is defined in Figure 2 .

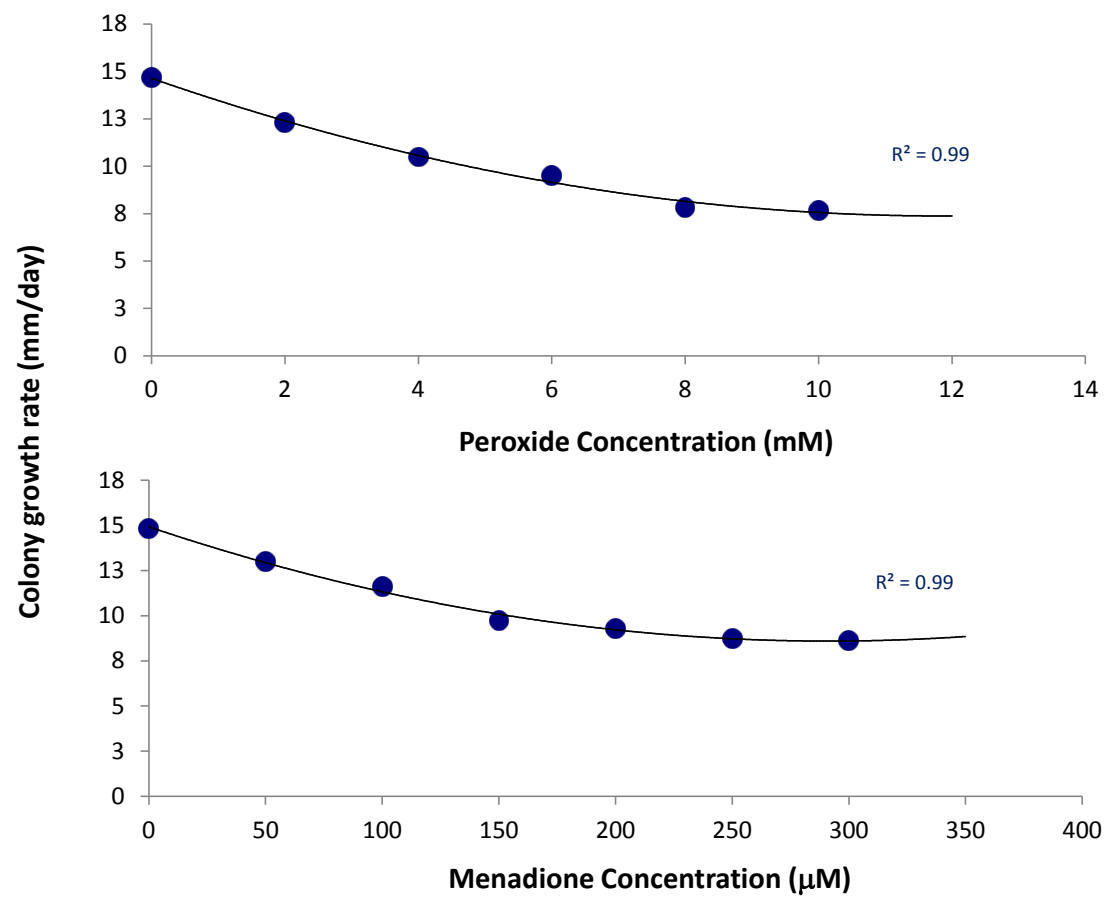

Figure 4. Oxidative stress sensitivity assays. Menadione (lower panel, 50 - $300 \mu \mathrm{M}$ ) or hydrogen peroxide (upper panel, $2-10 \mathrm{mM}$ ) containing PDA was used to assay $H$. maydis radial growth under conditions oxidative stress in the same way described in Figure 3. Values represent the average of six replicates. Error bars indicate standard error. The $R^{2}$ is defined in Figure 2.

\subsection{Oxidative Stress Sensitivity Assays}

To induce oxidative stress, we used the superoxide-releasing reagent menadione, peroxide and direct oxygenation. Both menadione and peroxide (used here at a maximum dosage of 33 times more than that of menadione) affected the colony growth rate in a dosage-dependent manner, but even high levels of these two compounds 


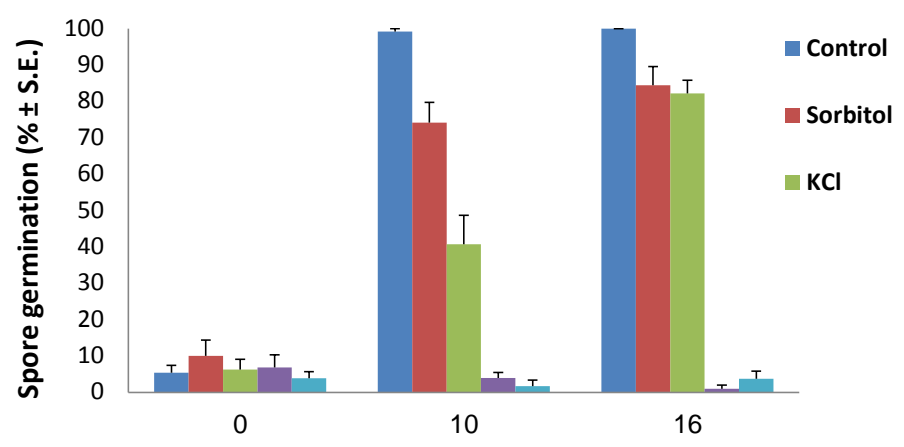

(a)

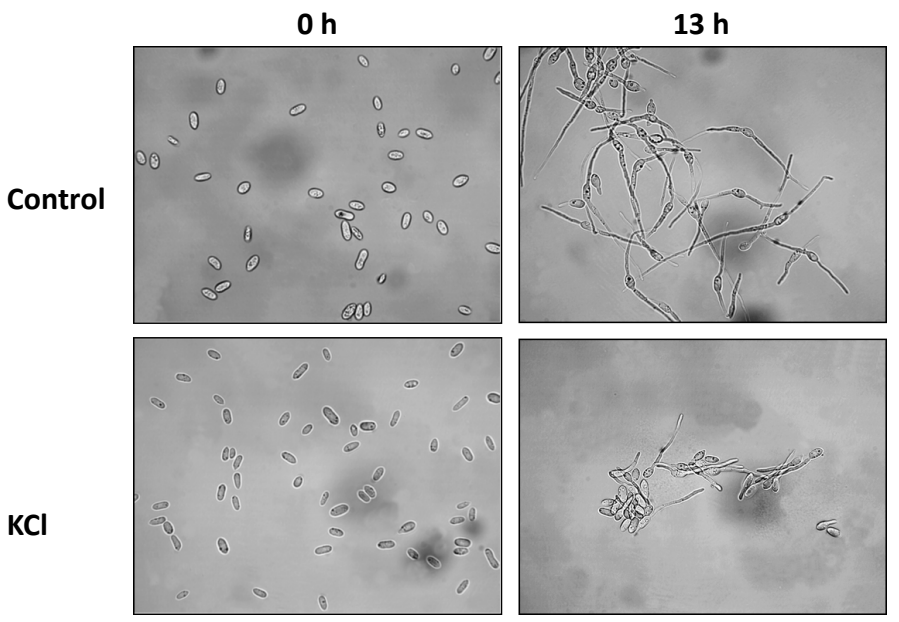

(b)

\begin{abstract}
Figure 5. Spore's germination assay to osmotic/ionic and oxidative stresses. H. maydis cultures were grown on PDA at $28^{\circ} \mathrm{C} \pm 1{ }^{\circ} \mathrm{C}$ in complete darkness. Spores were prepared and incubated in watery solutions containing $1.5 \mathrm{M}$ sorbitol, $0.75 \mathrm{M} \mathrm{KCl}, 200 \mu \mathrm{M}$ menadione or $10 \mathrm{mM}$ peroxide, as described in Figure 2. The control was double distilled water. (a) The percentage of germinating conidia determined after 0,10 and 16 hours by direct counting. Values represent the average of five replicates. Error bars indicate standard error. (b) Photograph of representative control and $0.75 \mathrm{M} \mathrm{KCl}$ spores solutions at the beginning of the experiment $(0 \mathrm{~h})$ and after 13 hours.
\end{abstract}

were unable to stop the fungal growth, reducing the growth rate only to half of its maximum rate (Figure 4). On the other hand, high levels of menadione or peroxide totally prevented the fungal spore from germinating, at the time period inspected (Figure 5). This suggests that the fungus, which is most likely to encounter the induced host oxidative burst response during the host vascular colonization and growth, is partly immune to this stress.

Since frequent watering or saturated soils reduced late wilt, it is possible that $H$. maydis is sensitive to low oxygen conditions [2]. Here, we tested the influence of excessive oxygen by enriching liquid cultures as described before [31]. Mycelia produced in cultures treated with mild oxygen enrichment (once a day with $\mathrm{O}^{2}$ for 1 min at a flow rate of 2 liter/min) grew at a rate higher than that of cultures grown with atmospheric air (Figure 6). In cultures flushed with pure $\mathrm{O}^{2}$ twice a day, this tendency was reversed and resulted in a significant $(P<$ $0.05)$ reduction in the fungal dry biomass. The same tendencies were measured for both wet and dry weight although the former (wet weight) revealed a better noticeable influence (Figure 6).

\title{
4. Discussion
}

During growth on maize leaves, $H$. maydis must contend with various kinds of physical and chemical ambient challenges such as light, temperature, $\mathrm{pH}$, oxidative, osmotic and other stresses. Therefore, collecting informa- 


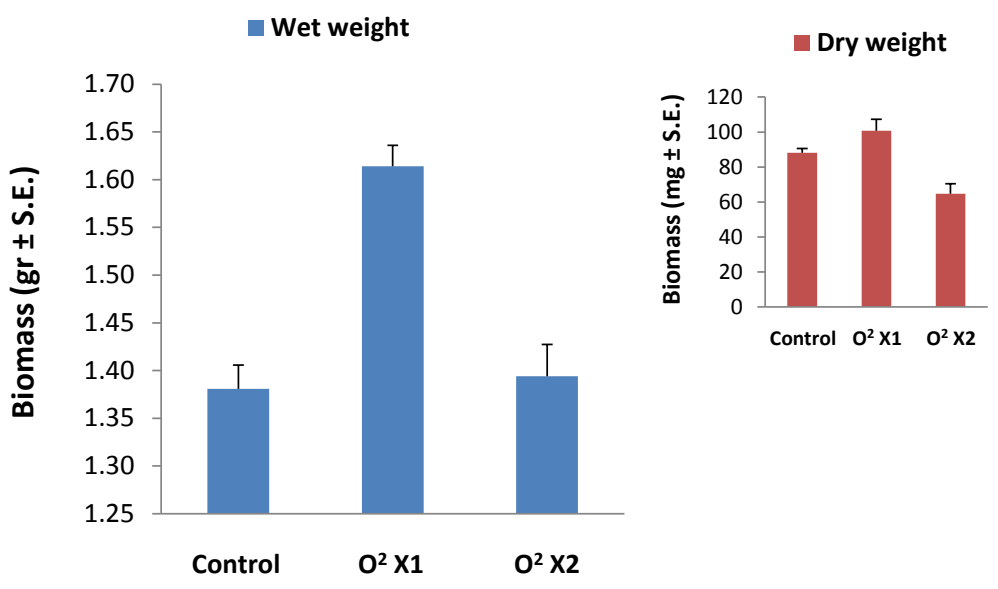

Figure 6. $H$. maydis cultures biomass in an oxygen enriched atmosphere. Submerged $150 \mathrm{ml}$ liquid cultures were grown at $28^{\circ} \mathrm{C} \pm 1^{\circ} \mathrm{C}$ in the dark on a rotary shaker at $150 \mathrm{rpm}$. The $250 \mathrm{ml}$ flasks were sealed with rubber stoppers, and the headspace was flushed once $\left(\mathrm{O}^{2} \mathrm{X} 1\right)$ or twice $\left(\mathrm{O}^{2} \mathrm{X} 2\right)$ a day with $\mathrm{O}^{2}$ for $1 \mathrm{~min}$ at a flow rate of 2 liter/min. Cultures grown with free exchange of atmospheric air (flasks sealed with dense paper plugs) served as controls. Cultures were incubated six days for the wet weight experiment or nine days for the dry weight experiment (insert). At the end of the experiment, the mycelium was harvested by filtrating it from the media using a Buchner funnel. The weight of the fungus was measured immediately (for wet weight) or after drying it at $70^{\circ} \mathrm{C}$ for 48 hours (for dry weight, insert). The wet weight assay was performed in three replications and the dry weight assay in six replications.

tion on the effects of these factors on in vitro mycelial growth and spore germination is important for gaining a better understanding of the pathogen and its relationship with the host plant. The ability of $H$. maydis to adjust to its natural habitat is exemplified by its preferable growth rate in the dark (Figure 1). Another factor is ambient $\mathrm{pH}$. Many fungi grow over a wide $\mathrm{pH}$ range and their gene expression is tailored to the environmental $\mathrm{pH}$ [34]. It is now widely accepted that appropriate responses to ambient $\mathrm{pH}$ govern fungal virulence in plants and other organisms [34]. The favorable $\mathrm{pH}$ values for H. maydis growth were 5 - 6 (Figure 2), indicating that this fungus adapts better to growth under moderate acid than neutral or alkali conditions. The relatively wide range of $\mathrm{pH}$ values that enabled fungus germination and proliferation ( $\mathrm{pH} 4-8$, Figure 2) is worrying since it may facilitate the pathogen spreading to various areas and soils, which occurred in Egypt [35] and Israel (Israel Northern R\&D, Migal-Galilee Research Institute, Kiryat Shmona, Israel, unpublished data).

Under deficit irrigation with saline water, a common water conserving practice, the crop experiences simultaneous matric and osmotic stresses [36]. The water status of the host and the environment caused by drought or hypertonic status can critically influence disease occurrence and severity [37]. Moreover, water stress and other abiotic factors, including transient episodes of stress such as soil salinity and root anoxia, affect root physiology to directly compromise host resistance, making roots and in some cases shoots more vulnerable to disease [38]. For example, Roubtsova et al. [37] exposed roots of Rhododendron hybrid Cunningham's White and Viburnum tinus cv. to infection by Phytophthora ramorum and examined the potential for mild abiotic stress in disease predisposition. A post-infection episode of salt stress to inoculated roots in the hydroponic regime resulted in significantly faster development of stem lesions in Rhododendron relative to non-stressed inoculated plants.

For many fungi, germination occurred at a lower water potential than growth. Some authors [39] [40] reported that germination was usually followed by growth; however, others [41] [42] reported similar effects to those observed here. Induced salt stress had a pronounced restricting effect on H. maydis hyphal development (Figure 3 ) but a weaker, yet significant, impact on spore germination (Figure 5). It would be of interest to know the occurrence and behavior of the pathogen in the soil environment, its ability to initiate root infections, and disease progression and severity under the influence of the hypertonic regime.

Water availability may be the most important environmental factor influencing microbial numbers and activities in unsaturated zones [43]. Indeed we have been inspecting maize plants that developed in late wilt infested grounds over the past five years (growing seasons) (Israel Northern R \& D, Migal-Galilee Research Institute, 
Kiryat Shmona, Israel, unpublished data). The accumulating evidence suggeststhat first emergence and progression of late wilt disease symptoms are subject to environmental and host physiological changes. In susceptible maize cultivars such as Jubilee, the first symptoms of wilting usually appeared in the field 50 - 60 days after sowing, shortly before the tasseling stage [8] [15]. Nevertheless, when we used a drip irrigation line for each row (which provides better irrigation) instead of a frontal irrigation system, plants reached $70 \%$ silk 60 days after sowing and the first disease symptoms appeared only 10 days later (70 days after seeding) [44].

Reviewing the literature revealed that the high level of oxygen in the ground resulting from low water potential is one of the most important factors enhancing late wilt disease progression. Flood fallowing increases anaerobic conditions, stimulates lytic organisms to degrade sclerotia and reduces survival potential. Early sowing of corn in Egypt reduced late wilt [21], while late summer planting reduced disease severity in India [45]. Unfavorable soil conditions with low rainfall may be the determining factor with a reported date of seeding effects [45]. Moisture stress is a major predisposing factor for late wilt [24], and frequent watering or saturated soils reduced late wilt [2]. It was reported that corn did not develop late wilt following paddy-cultivated rice, which increases the availability of $\mathrm{Mn}$ for subsequent crops, although $H$. maydis is also sensitive to low oxygen conditions [2].

The data presented here are in agreement with this line of evidences. The pathogen colonies grown under a high oxygen atmosphere exhibited an increased growth rate (Figure 6). However, excessive oxygen can result in induced ROS that can suppress the fungal development as reported here (Figure 4 and Figure 5). Interestingly $H$. maydis spores were much more susceptible to hydrogen peroxide or the superoxide-generating agent menadione (Figure 5) than the hypha that grew at a mild rate in relatively high concentrations of these oxidative agents (Figure 4). In Saccharomyces cerevisiae, pretreatment with menadione protects against cell killing by hydrogen peroxide; however, pretreatment with hydrogen peroxide is unable to protect cells from a subsequent challenge with menadione [46]. This suggests that the adaptive responses to these two different oxidants may be distinct. It will be interesting to further investigate these and other aspects regarding the ability of $H$. maydis to cope with these oxidative stresses, especially with respect to maize cultivars differentiated in their susceptibility/ resistance to the disease.

An increase in average commercial maize yield in the US is associated with increased stress tolerance, which is consistent with an improvement in the genotype $\times$ management interaction [47] [48]. The observations indicate that a common mechanism may exist, which has not yet been elucidated, that improves crops' tolerance to a variety of stresses. Moreover, the potential for future yield improvement through increased stress tolerance of maize in the US is large, as yield potential is approximately three times greater than current commercial maize yields [47]. Environmental stress tolerance and disease resistance may be linked to each other. The cultivars of maize Giza 2 (G2) was observed to be more resistant to late wilt disease and also more tolerant to water stress and a combination of both factors than Population 45 (P45) cultivars [24].

Invasion of the maize plant host by $H$. maydis is most likely affected by oxidative stress resulting from host responses, the activity of lignin-degrading enzymes produced by the fungus, such as phenol-oxidase (laccase) and superoxide production by nitric oxide synthase (NOS). ROS, which play a central role in plant pathogen defense, may be perturbed by a number of adverse abiotic stress factors such as high light, drought, low temperature, high temperature and mechanical stress [29]. Both oxidative burst following pathogen challenge and exposure to abiotic stresses can result in PCD (programmed cell death) [49]. However, the role that ROS plays during abiotic stresses appears to be opposite to the role played during pathogen defense. Upon abiotic stresses, ROS scavenging enzymes are induced to decrease the concentration of toxic intracellular ROS levels [29]. These considerations raise the question of how plants can regulate ROS production and scavenging mechanisms when they are exposed simultaneously to pathogen attack and abiotic stress. Evidence of the significance of such conflicting situations comes from experiments with tobacco plants showing that oxidative stress pretreatment resulted in increased levels of ROS scavenging enzymes, leading to hypersensitivity to the pathogen infection [50].

In this study, light, $\mathrm{pH}$, salinity (osmotic/ionic) and oxidative stress were selected to examine their influence on $H$. maydis. Late wilt is currently considered to be the most serious maize disease in Israel and its constant spread in the last decade may be defined it as epidemic. The ability of the pathogen to overcome different environmental conditions, may explain its spread in Israel to a very different climatic zones. Although this work focused on each stress individually under conventional ambient conditions, future efforts should address the combined effect of these environmental conditions as demonstrated earlier [41]. An effort to understand pathogen 
growth limitation under various ambient stress conditions, as was conducted here, may help recognize its weak points and assist in locating effective means that could be applied in the field to reduce late wilt economic losses.

\section{Acknowledgements}

We would like to thank Dana Natanzon (Migal-Galilee Research Institute, Israel), Moran Werner, Yaniv Levin and Dudi Hochberg (Tel-Hai College, Israel) for their technical assistance. This work was supported by a research grant from the Israel Plant Council, the Ministry of Agriculture and a research grant from the Jewish National Fund (Keren Kayemeth Leisrael).

\section{References}

[1] Grillo, G., Michail, S.H., Abou-Elseoud, M.S. and Nour Eldin, M.S. (1999) Seed Health Testing of Corn for Cephalosporium maydis. Acta Phytopathologica et Entomologica Hungarica, 34, 35-42.

[2] Samra, A.S., Sabet, K.A. and Abdel-Rahim, M.F. (1996) Effect of Soil Conditions and Cultural Practices on Infection with Stalk Rots. UAR Ministry of Agric, Government Printing Offices, Cairo.

[3] Gams, W. (1971) Cephalosporium-Artige. Schimmelpilze (Hyphomycetes), G. Fischer, Stuttgart.

[4] Zeller, K.A., Jurgenson, J.E., El-Assiuty, E.M. and Leslie, J.F. (2000) Isozyme and Amplified Fragment Length Polymorphisms from Cephalosporium maydis in Egypt. Phytoparasitica, 28, 121-130. http://dx.doi.org/10.1007/BF02981741

[5] Sabet, K.A., Samra, A.S., Hingorani, M.K. and Mansour, I.M. (1961) Stalk and Root Rots of Maize in the United Arab Republic. FAO Plant Protection Bulletin, 9, 121-125.

[6] Payak, M.M., Lal, S., Lilaramani, J. and Renfro, B.L. (1970) Cephalosporium maydis-A New Threat to Maize in India. Indian Phytopathology, 23, 562-569.

[7] Pecsi, S. and Nemeth, L. (1998) Appearance of Cephalosporium maydis Samra Sabet and Hingorani in Hungary. 50th International Symposium on Crop Protection, Ghent, 5 May 1998, 873-877.

[8] Drori, R., Sharon, A., Goldberg, D., Rabinovitz, O., Levy, M. and Degani, O. (2012) Molecular Diagnosis for Harpophora maydis, the Cause of Maize Late Wilt in Israel. Phytopathologia Mediterranea, 52, 16-29. http://www.fupress.net/index.php/pm/article/view/10824

[9] Molinero-Ruiz, M.L., Melero-Vara, J.M. and Mateos, A. (2011) Cephalosporium maydis, the Cause of Late Wilt in Maize, a Pathogen New to Portugal and Spain. Plant Disease, 94, 379. http://dx.doi.org/10.1094/PDIS-94-3-0379A

[10] Johal, L., Huber, D.M. and Martyn, R. (2004) Late Wilt of Corn (Maize) Pathway Analysis: intentional Introduction of Cephalosporium maydis. Pathways Analysis for the Introduction to the U.S. of Plant Pathogens of Economic Importance. US Department of Agriculture, Animal and Plant Health Inspection Service. Technical Report No. 503025.

[11] Warren, H.L. (1983) Potential Disease Problems: Late Wilt of Maize. Phytopathology, 73, 782.

[12] El-Assiuty, E.M., Ismael, A.M., Zeller, K.A. and Leslie, J.F. (1999) Relative Colonization Ability of GreenhouseGrown Maize by Four Lineages of Cephalosporium maydis from Egypt. Phytopathology, 89, S23.

[13] Saleh, A.A., Zeller, K.A., Ismael, A.S., Fahmy, Z.M., El-Assiuty, E.M. and Leslie, J.F. (2003) Amplified Fragment Length Polymorphism Diversity in Cephalosporium maydis from Egypt. Phytopathology, 93, 853-859. http://dx.doi.org/10.1094/PHYTO.2003.93.7.853

[14] Zeller, K.A., Abou-Serie, M.I., El-Assuity, E.M., Fahmy, Z.M., Bekheet, F.M. and Leslie, J.F. (2002) Relative Competitiveness and Virulence of Four Clonal Lineages of Cephalosporium maydis from Egypt Toward Greenhouse-Grown Maize. Plant Disease, 86, 373-378. http://dx.doi.org/10.1094/PDIS.2002.86.4.373

[15] Sabet, K.A., Zaher, A.M., Samra, A.S. and Mansour, I.M. (1970) Pathogenic Behaviour of Cephalosporium maydis and C. acremonium. Annals of Applied Biology, 66, 257-263. http://dx.doi.org/10.1111/j.1744-7348.1970.tb06432.x

[16] Degani, O. and Cernica, G. (2014) Diagnosis and Control of Harpophora maydis, the Cause of Late Wilt in Maize. Advances in Microbiology, 4, 94-105. http://dx.doi.org/10.4236/aim.2014.42014

[17] El-Shafey, H.A. and Claflin, L.E. (1999) Late Wilt. APS Press, St. Paul.

[18] Samra, A.S., Sabet, K.A. and Hingorani, M.K. (1962) A New Wilt Disease of Maize in Egypt. Plant Disease Reporter, 46, 481-483.

[19] Shehata, F.A. (1976) The Inheritance of Resistence to Late Wilt Caused by Cephalosporium maydis in Some Corn Lines. Faculty of Agriculture, Al-Azhar, Cairo.

[20] Singh, S.D. and Siradhana, B.S. (1987) Influence of Some Environmental Conditions on the Development of Late Wilt 
of Maize Induced by Cephalosporium maydis. Indian Journal of Mycology and Plant Pathology, 17, 1-5.

[21] El-Shafey, H.A., El-Shorbagy, F.A., Khalil, I.I. and El-Assiuty, E.M. (1988) Additional Sources of Resistance to the Late-Wilt Disease of Maize Caused by Cephalosporium maydis. Agricultural Research Review, 66, 221-230.

[22] Sabet, K.A., Samra, A.S. and Mansour, I.M. (1970) Saprophytic Behaviour of Cephalosporium maydis and C. acremonium. Annals of Applied Biology, 66, 265-271. http://dx.doi.org/10.1111/j.1744-7348.1970.tb06433.x

[23] Schneider, R. and Pendery, W. (1983) Stalk Rot of Corn: Mechanism of Predisposition by an Early Season Water Stress. Phytopathology, 73, 863-871. http://dx.doi.org/10.1094/Phyto-73-863

[24] Abd El-Rahim, M.F., Fahmy, G.M. and Fahmy, Z.M. (1998) Alterations in Transpiration and Stem Vascular Tissues of Two Maize Cultivars under Conditions of Water Stress and Late Wilt Disease. Plant Pathology, 47, 216-223. http://dx.doi.org/10.1046/j.1365-3059.1998.00211.x

[25] Talboys, P.W. (1968) Water Deficits in Vascular Disease. Academi Press, New York.

[26] Samra, A.S., Sabet, K.A. and Hingorani, M.K. (1963) Late Wilt Disease of Maize Caused by Cephalosporium maydis. Phytopathology, 53, 402-406.

[27] Singh, S.D. and Siradhana, B.S. (1987b) Survival of Cephalosporium maydis, Incitant of Late Wilt of Maize. Indian Journal of Mycology and Plant Pathology, 17, 83-85.

[28] Degani, O. (2013) Cochliobolus heterostrophus G-Protein Alpha and Beta Subunit Double Mutant Reveals Shared and Distinct Roles in Development and Virulence. Physiological and Molecular Plant Pathology, 82, 35-45. http://dx.doi.org/10.1016/j.pmpp.2013.01.004

[29] Apel, K. and Hirt, H. (2004) Reactive Oxygen Species: Metabolism, Oxidative Stress, and Signal Transduction. Annual Review of Plant Biology, 55, 373-399. http://dx.doi.org/10.1146/annurev.arplant.55.031903.141701

[30] Hassan, H.M. and Fridovich, I. (1979) Intracellular Production of Superoxide Radical and of Hydrogen Peroxide by Redox Active Compounds. Archives of Biochemistry and Biophysics, 196, 385-395. http://dx.doi.org/10.1016/0003-9861(79)90289-3

[31] Belinky, P.A., Flikshtein, N., Lechenko, S., Gepstein, S. and Dosoretz, C.G. (2003) Reactive Oxygen Species and Induction of Lignin Peroxidase in Phanerochaete chrysosporium. Applied and Environmental Microbiology, 69, 65006506. http://dx.doi.org/10.1128/AEM.69.11.6500-6506.2003

[32] Dute, R., Weete, J. and Rushing, A. (1989) Ultrastructure of Dormant and Germinating Conidia of Aspergillus ochraceus. Mycologia, 81, 772-782. http://dx.doi.org/10.2307/3759882

[33] Hobot, J. and Gull, K. (1981) Changes in the Organisation of Surface Rodlets during Germination of Syncephalastrum racemosum Sporangiospores. Protoplasma, 107, 339-343. http://dx.doi.org/10.1007/BF01276834

[34] Peñalva, M.A., Tilburn, J., Bignell, E., and Arst Jr, H.N. (2008) Ambient pH Gene Regulation in Fungi: Making Connections. Trends in Microbiology, 16, 291-300. http://dx.doi.org/10.1016/j.tim.2008.03.006

[35] Galal, A.A., El-Rouby, M.M. and Gad, A.M. (1979) Genetic Analysis of Resistance to Late Wilt (Cephalosporium maydis) in Variety Crosses of Maize. Zeitschrift fur Planzenzuchtung, 83, 176-183.

[36] Shani, U. and Dudley, L. (2001) Field Studies of Crop Response to Water and Salt Stress. Soil Science Society of America Journal, 65, 1522-1528. http://dx.doi.org/10.2136/sssaj2001.6551522x

[37] Roubtsova, T.V. and Bostock, R.M. (2009) Episodic Abiotic Stress as a Potential Contributing Factor to Onset and Severity of Disease Caused by Phytophthora ramorum in Rhododendron and Viburnum. Plant Disease, 93, 912-918. http://dx.doi.org/10.1094/PDIS-93-9-0912

[38] Boyer, J.S. (1995) Biochemical and Biophysical Aspects of Water Deficits and the Predisposition to Disease. Annual Review of Phytopathology, 33, 251-274. http://dx.doi.org/10.1146/annurev.py.33.090195.001343

[39] Pitt, J. and Christian, J. (1968) Water Relations of Xerophilic Fungi Isolated from Prunes. Applied Microbiology, 16, 1853-1858.

[40] Wheeler, K.A., Hocking, A.D. and Pitt, J. (1988) Water Relations of Some Aspergillus Species Isolated from Dried Fish. Transactions of the British Mycological Society, 91, 631-637. http://dx.doi.org/10.1016/S0007-1536(88)80038-X

[41] Gock, M.A., Hocking, A.D., Pitt, J.I. and Poulos, P.G. (2003) Influence of Temperature, Water Activity and pH on Growth of Some Xerophilic Fungi. International Journal of Food Microbiology, 81, 11-19. http://dx.doi.org/10.1016/S0168-1605(02)00166-6

[42] Hocking, A.D. and Pitt, J. (1979) Water Relations of Some Penicillium Species at $25^{\circ}$ C. Transactions of the British Mycological Society, 73, 141-145. http://dx.doi.org/10.1016/S0007-1536(79)80084-4

[43] Kieft, T., Amy, P., Brockman, F., Fredrickson, J., Bjornstad, B. and Rosacker, L. (1993) Microbial Abundance and Activities in Relation to Water Potential in the Vadose Zones of Arid and Semiarid Sites. Microbial Ecology, 26, 59-78. http://dx.doi.org/10.1007/BF00166030 
[44] Degani, O., Weinberg, T. and Graph, S. (2014) Chemical Control of Maize Late Wilt in the Field. Phytoparasitica, Published Online. http://dx.doi.org/10.1007/s12600-014-0394-5

[45] Singh, S.D. and Siradhana, B.S. (1988) Date of Sowing in Relation to Late Wilt Disease of Maize. Indian Phytopathology, 41, 489-491.

[46] Jamieson, D.J. (1992) Saccharomyces cerevisiae has Distinct Adaptive Responses to both Hydrogen Peroxide and Menadione. Journal of Bacteriology, 174, 6678-6681.

[47] Tollenaar, M. and Lee, E.A. (2002) Yield Potential, Yield Stability and Stress Tolerance in Maize. Field Crops Research, 75, 161-169. http://dx.doi.org/10.1016/S0378-4290(02)00024-2

[48] Tollenaar, M. and Wu, J. (1999) Yield Improvement in Temperate Maize is Attributable to Greater Stress Tolerance. Crop Science, 39, 1597-1604. http://dx.doi.org/10.2135/cropsci1999.3961597x

[49] Wohlgemuth, H., Mittelstrass, K., Kschieschan, S., Bender, J., Weigel, H.J., Overmyer, K., Kangasjärvi, J., Sandermann, H. and Langebartels, C. (2002) Activation of an Oxidative Burst is a General Feature of Sensitive Plants Exposed to the Air Pollutant Ozone. Plant, Cell and Environment, 25, 717-726. http://dx.doi.org/10.1046/j.1365-3040.2002.00859.x

[50] Mittler, R., Herr, E.H., Orvar, B.L., van Camp, W., Willekens, H., Inzé, D. and Ellis, B.E. (1999) Transgenic Tobacco Plants with Reduced Capability to Detoxify Reactive Oxygen Intermediates are Hyperresponsive to Pathogen Infection. Proceedings of the National Academy of Sciences of the United States of America, 96, 14165-14170. http://dx.doi.org/10.1073/pnas.96.24.14165 